\title{
Pharmacological Activity and Phytochemical Profile of Acacia Heartwood Extracts
}

\author{
Yanico Hadi Prayogo ${ }^{1}$, Wasrin Syafii ${ }^{1, *}$, Rita Kartika Sari ${ }^{1}$, Irmanida Batubara ${ }^{2,3}$ (D) and Danu 4 \\ 1 Department of Forest Products, Faculty of Forestry and Environment, IPB University, Bogor 16680, Indonesia; \\ yanicohadi@apps.ipb.ac.id (Y.H.P.); rita_kbu@yahoo.com (R.K.S.) \\ 2 Department of Chemistry, Faculty of Natural Sciences and Mathematics, IPB University, \\ Bogor 16680, Indonesia; ime@apps.ipb.ac.id \\ 3 Tropical Biopharmaca Research Center, IPB University, Bogor 16128, Indonesia \\ 4 Forest Tree Seed Technology Research and Development Institute, Bogor 16001, Indonesia; \\ danu_bptp@yahoo.co.id \\ * Correspondence: wasrinsy@apps.ipb.ac.id
}

Citation: Prayogo, Y.H.; Syafii, W.;

Sari, R.K.; Batubara, I.; Danu.

Pharmacological Activity and Phytochemical Profile of Acacia Heartwood Extracts. Sci. Pharm. 2021,

89, 37. https://doi.org/

10.3390/scipharm 89030037

Academic Editor: Helen D. Skaltsa

Received: 8 June 2021

Accepted: 29 July 2021

Published: 4 August 2021

Publisher's Note: MDPI stays neutral with regard to jurisdictional claims in published maps and institutional affiliations.

Copyright: (c) 2021 by the authors. Licensee MDPI, Basel, Switzerland. This article is an open access article distributed under the terms and conditions of the Creative Commons Attribution (CC BY) license (https:// creativecommons.org/licenses/by/ $4.0 /)$.
Abstract: Reactive oxygen species (ROS) are related to several degenerative diseases. In this study, Acacia, a genus with many fast-growing species, was investigated to explore the many phytochemical compounds that are biologically active in processes dealing with ROS-related diseases. This study aimed to select extracts of Acacia heartwood on the basis of their pharmacological and phytochemical profiles and identify their bioactive compounds. Five methanolic extracts from Acacia heartwood were evaluated for their antioxidant activity using three different in vitro assays: toxicity toward Artemia salina and phenolic and polyphenolic content. Multivariate analysis was conducted to select two promising extracts and then their bioactive compounds were identified using liquid chromatography coupled with mass spectrometry. Acacia crassicarpa extracts showed the highest antioxidant activity, as well as phenolic and hydrolyzable tannin contents, but low toxicity. The $A$. mangium extract exhibited high flavonoid and condensed tannin content, whereas A. decurrrens had the highest toxicity with low antioxidant activity. Pearson's correlation analysis demonstrated no correlation between antioxidant activity and toxicity. Moreover, the phytochemical profile exhibited an association with pharmacological parameters. Principal component analysis followed by cluster analysis divided the extracts into three clusters. Two heartwood extracts of $A$. crassicarpa and A. auriculiformis were chosen as the best extracts. Identification showed that these extracts were dominated by phenolic compounds, as well as anthraquinone and xanthone.

Keywords: Acacia; antioxidant; toxicity; phytochemical profile; multivariate analysis

\section{Introduction}

Reactive oxygen species (ROS) are components produced by reactions in cells that are widely associated with growth in humans. Excessive ROS production can lead to oxidative stress in cells, which is the cause of many chronic and degenerative diseases, such as cancer, as well as cardiovascular, neurological, sensory, and psychiatric diseases [1]. Cancer is a disease associated with oxidative stress [2]. In 2018, the number of new cancer patients in Indonesia was 348,809, with breast cancer most commonly occurring in women and lung cancer most commonly occurring in men [3]. Chemotherapy is a treatment applied to kill cancer cells, but this treatment also has effects on normal cells because some drugs can lead to ROS formation, such as doxorubicin [4]. ROS formation renders chemotherapy ineffective, causing the dysfunction of cell organelles $[5,6]$.

Antioxidants, especially plant-derived antioxidants, are an option used to treat ROS generation due to chemotherapy treatment, reducing its toxicity toward normal cells. They are present in various parts of plants, including heartwood, which contains a highly extractive component compared to sapwood. Previous studies have highlighted the antioxidant activities of extractive components from several genera, namely Cryptomeria, 
Acacia, Artocarpus, and Caesalpinia [7-10]. Among other genera, Acacia is interesting as it is known to include many fast-growing species. Previous reports have also demonstrated the antioxidant activities of several heartwood extracts from the Acacia species, namely $A$. cathecu, A. mangium, $A$. auriculiformis, $A$. sensu, and $A$. confusa $[8,11,12]$. In terms of toxicity, the heartwood extracts from the Acacia genus showed cytotoxicity toward some carcinoma cells, namely human breast carcinoma and hepatocarcinoma cells [11,13]. In addition, other parts of Acacia also showed biological activity with antidiabetic, anti-acetylcholinesterase, antipyretic, and anti-inflammatory properties [14-16].

The Acacia genus, which belongs to the Fabaceae family, is one of the many tree genera easily found in Indonesia. Several species of this genus can grow quickly and are easy to cultivate; for example, A. mangium [17], A. auriculiformis [18], and A. crassicarpa [19]. This growth rate has led to several members of Acacia being categorized as invasive alien species in Europe [20]. Another species, A. deccurens, was designated a weed plant on Mount Merapi [21] and in South Africa [22]. In addition, A. leuchoploea has good durability, and it is widely found in Timor and Java Island on various land types [23]. According to Statistics Indonesia, in 2017 and 2018, the national log production in Indonesia was dominated by Acacia wood at $63.36 \%$ of 49.13 million $\mathrm{m}^{3}$ and $57.35 \%$ of 55.52 million m ${ }^{3}$ total log production in 2017 and 2018, respectively, mostly sourced from Sumatera and Kalimantan [24,25].

Due to the similarity of the secondary metabolite compounds of this genus and its ability to grow and adapt well, Acacia trees are able to provide sufficient raw materials for development and exploration as a potential source of biopharmaceuticals for the treatment of ROS-related diseases. Therefore, this study aimed to select Acacia heartwood extracts on the basis of their in vitro antioxidant activities, toxicities, and phytochemical profiles and identify the bioactive compounds in the selected extracts. We evaluated five species of Acacia growing in Indonesia: A. mangium Willd., A. auriculiformis Benth., A. decurrens Willd., A. leuchoploea (Roxb) Willd., and A. crassicarpa Cunn. ex Benth.

\section{Materials and Methods}

\subsection{Materials}

The plant materials of $A$. mangium, . auriculiformis, and A. crassicarpa wood samples were harvested from the forest plantation in Bogor (West Java, Indonesia), whereas A. leucophloea and A. deccurens samples were from Blora and Pekalongan (Central Java, Indonesia), respectively. All species were identified and confirmed by the Research Center of Biology at the Indonesian Institute of Science. Voucher specimens were deposited at the Tropical Biopharmaca Research Center, IPB University (BMK0484072021, BMK0485072021, BMK0486072021, BMK0487072021, and BMK0489072021). The chemicals used were methanol (analytical grade), Folin-Ciocâlteu reagent, $\mathrm{Na}_{2} \mathrm{CO}_{3}, \mathrm{AlCl}_{3}$, $\mathrm{CH}_{3} \mathrm{COOK}, \mathrm{HCl}$, vanillin, $\mathrm{KIO}_{3}$, 1,1-diphenyl-2-picrylhydrazyl, 2,2-azino-bis(3ethylbenzothiazoline-6-sulfonic acid), $\mathrm{K}_{2} \mathrm{~S}_{2} \mathrm{O}_{8}$, aqua bidest, 2,4,6-tri(2-pyridyl)-s-triazine (in $4 \mathrm{mM} \mathrm{HCl}$ ), $\mathrm{FeCl}_{3}$, and deionized water.

\subsection{Extraction of Acacia Heartwood}

The heartwoods were separated from bark and sapwood, cut into chips, and airdried. The dried chip woods were converted and then screened to obtain 40-60 mesh sawdust. The sawdust was then used for further analysis. The water content of the sawdust was measured before the extraction process. A total of $500 \mathrm{~g}$ of heartwood sawdust was immersed in methanol solvent with a sawdust-to-solvent ratio of 1:5 for $24 \mathrm{~h}$, and this was repeated three times. The extract was then concentrated using a rotary evaporator and weighed to obtain the yields.

\subsection{Determination of Phytochemical Profile}

Total phenolic content (TPC) was determined according to Batubara et al. (2020) [26]; a total of $10 \mu \mathrm{L}$ of extract solution was added to the microplate well, along with $150 \mu \mathrm{L}$ 
of aqua bidest, $10 \mu \mathrm{L}$ of $10 \%$ Folin-Ciocâlteu reagent, and $20 \mu \mathrm{L}$ of $10 \% \mathrm{Na}_{2} \mathrm{CO}_{3}$. The mixture was homogenized and incubated for $30 \mathrm{~min}$ at room temperature. Absorbances were measured at $750 \mathrm{~nm}$ using a microplate reader (Epoch Biotek, Winooski, VT, USA). A gallic acid calibration curve was generated, and the phenolic content was reported in milligrams of gallic acid equivalent per gram of dried extract (mg GAE/g DE).

Total flavonoid content (TFC) was determined according to Batubara et al. (2020) [26]; a total of $60 \mu \mathrm{L}$ of extract solution was mixed with $10 \mu \mathrm{L}$ of $10 \% \mathrm{AlCl}_{3}, 10 \mu \mathrm{L}$ of $\mathrm{CH}_{3} \mathrm{COOK}_{\text {, }}$ and $120 \mu \mathrm{L}$ of aqua bidest. Then, the sample solution was incubated at room temperature for $30 \mathrm{~min}$. Measurements were carried out using a microplate reader at $415 \mathrm{~nm}$. Calibration curves were prepared using quercetin standards, and total flavonoid levels were expressed as milligrams of quercetin equivalent per gram of dried extract (mg QE/g DE).

The condensed tannin (CT) content was determined according to Herald et al. (2014) [27]; $30 \mu \mathrm{L}$ of sample in a 96-well microplate was mixed with $150 \mu \mathrm{L}$ of $\mathrm{HCl}-$ vanillin reagent (1\% vanillin mixed with $8 \% \mathrm{HCl}$ in a ratio of $1: 1)$ in methanol. The test solution was then incubated at room temperature for $20 \mathrm{~min}$. Absorbance was measured using a microplate reader at a wavelength of $500 \mathrm{~nm}$. Catechin standard compounds were used to create calibration curves with a concentration range of $60-900 \mathrm{mg} \cdot \mathrm{L}^{-1}$. The value of the condensed tannin content was expressed as milligrams of catechin equivalent per gram of dried extract (mg CE/g DE).

The hydrolyzable tannin (HT) content was determined according to Akter et al. (2019) [28]. A total of $50 \mu \mathrm{L}$ of sample in a 96-well microplate was mixed with $150 \mu \mathrm{L}$ of $\mathrm{KIO}_{3} 2.5 \%$ reagent in aqua bidest. The test solution was then incubated at room temperature for $15 \mathrm{~min}$. Tannic acid standard compounds were used to create calibration curves with a concentration range of $60-1500 \mathrm{mg} \cdot \mathrm{L}^{-1}$. The absorbance measurement was done using a microplate reader at a wavelength of $550 \mathrm{~nm}$. The value of the condensed tannin content was expressed as milligrams of tannic acid equivalent per gram of dried extract (mg TAE/g DE).

\subsection{Determination of Antioxidant Capacity}

For the 1,1-diphenyl-2-picrylhydrazyl (DPPH) assay [29], a total of $100 \mu \mathrm{L}$ of DPPH radical solution in methanol with a concentration of $125 \mu \mathrm{M}$ was added to $100 \mu \mathrm{L}$ of the extract solution in a 96-well plate. The samples were then incubated at room temperature for $30 \mathrm{~min}$. Furthermore, the absorbance of each mixture was measured using a microplate reader (Epoch Biotek, USA) at a wavelength of $515 \mathrm{~nm}$.

For the ferric reducing antioxidant power (FRAP) assay [29], the FRAP reagent was prepared by mixing $300 \mathrm{mM}$ acetate buffer solution pH 3.6, $10 \mathrm{mM}$ 2,4,6-tri(2-pyridyl)$s$-triazine (in $4 \mathrm{mM} \mathrm{HCl}$ ), and $20 \mathrm{mM} \mathrm{FeCl}_{3}$ (in deionized water) in a ratio of 10:1:1. A total of $10 \mu \mathrm{L}$ of each extract sample was mixed with $300 \mu \mathrm{L}$ of FRAP reagent in a 96-well microplate. The samples were incubated for $40 \mathrm{~min}$ at $37^{\circ} \mathrm{C}$ in an incubator. Subsequently, the absorbance of the solution was observed at $593 \mathrm{~nm}$ using a microplate reader (Epoch Biotek, USA).

For the 2,2-azino-bis(3-ethylbenzothiazoline-6-sulfonic acid) (ABTS) assay [29,30], a total of $5 \mathrm{~mL}$ of $7 \mathrm{mM}$ ABTS reagent (in aqua bidest.) was mixed with $88 \mu \mathrm{L}$ of $\mathrm{K}_{2} \mathrm{~S}_{2} \mathrm{O}_{8}$ $140 \mathrm{mM}$ (in aqua bidest). The mixture was then stored in a dark room for $16 \mathrm{~h}$ and consequently diluted using aqua bidest in a ratio of 1:44 $(v / v)$. Sample solutions were prepared by mixing $180 \mu \mathrm{L}$ of ABTS reagent with $20 \mu \mathrm{L}$ of extract solution in a 96-well microplate, before incubating at room temperature for $6 \mathrm{~min}$. After incubation, the absorbance was measured using a microplate reader at a wavelength of $734 \mathrm{~nm}$.

The measurements were done in triplicate, and an absorbance control was also evaluated in each assay. A calibration curve was generated using Trolox standard as the positive control. Then, the extract absorbance denoting antioxidant capacity was expressed as millimoles of Trolox equivalent per gram of dried extract (mmol TE/g DE). 


\subsection{Determination of Toxicity toward Artemia salina Leach}

A brine shrimp lethality test (BSLT) was carried out according to previous reports with slight modification [31,32]. The eggs of Artemia salina were placed into a container filled with preconditioned seawater (filtered using a $1 \mu \mathrm{m}$ filter and aerated for $24 \mathrm{~h}$ ). Eggs were incubated under a lamp and aerated for hatching the egg into larvae. The $48 \mathrm{~h}$ old larvae were used for toxicity testing. Furthermore, larvae were separated by pipetting them into a 36-well plate. The concentration range used in the test was $125-2000 \mu \mathrm{g} \cdot \mathrm{mL}^{-1}$, with a total volume of $2 \mathrm{~mL}$ of the test solution containing $10 \mathrm{~A}$. salina larvae. The multi-well plate was closed and left under a lamp. Observations were made $24 \mathrm{~h}$ after administering the extract by counting the number of $A$. salina larvae that died. The $\mathrm{LC}_{50}$ (median lethal concentration) value was determined by plotting the percentage of mortality described as a probit value against the log of the test concentration.

\subsection{Data Analysis}

Each measurement was done in triplicate (except for extraction). The antioxidant capacity, toxicity, and phytochemical profile were analyzed using a completely randomized design method and analysis of variance (ANOVA) at the $95 \%$ confidence interval, followed by Duncan's multiple-range test, with SPSS 25. Pearson's correlation matrix was constructed using RStudio (version 1.4.1106) with the PerformanceAnalytics package, whereas principal component analysis and cluster analysis were carried out using the FactoMineR and factoextra packages in RStudio.

\section{Results}

\subsection{Yield of Methanolic Extracts and Their Phytochemical Profile}

The extraction yield ranged from $2-8 \%$, and the heartwood of A. auriculiformis had a high yield percentage (8.591\%), along with A. mangium, compared to other extracts (Table 1). The phytochemical profiles of the five extracts as a function of phenolic/polyphenolic content showed varied trends among the four used methods (Table 1). The TPC had a range of 100-260 mg GAE/g DE, with the A. crassicarpa extract exhibiting the highest phenolic content $(259.09 \mathrm{mg}$ GAE/g DE; $p<0.05)$. A similar trend was observed for HT, with the A. crassicarpa extract (1055.77 mg TAE/g DE) showing the highest hydrolyzable tannin content; however, in this case, the A. decurrens and A. leucophloea extracts exhibited the lowest values in terms of TPC and HT, respectively $(p<0.05)$. Similar trends were also observed for TFC and CT; however, A. mangium extract exhibited the highest value for both parameters.

Table 1. The yields and phytochemical profiles of the five Acacia heartwood methanolic extracts.

\begin{tabular}{cccccc}
\hline Extracts & $\begin{array}{c}\text { Extraction Yield } \\
\text { (\%) }\end{array}$ & $\begin{array}{c}\text { TPC } \\
\text { (mg GAE/g DE) }\end{array}$ & $\begin{array}{c}\text { TFC } \\
\text { (mg QE/g DE) }\end{array}$ & $\begin{array}{c}\text { CT } \\
\text { (mg CE/g DE) }\end{array}$ & $\begin{array}{c}\text { HT } \\
\text { (mg TAE/g DE) }\end{array}$ \\
\hline A. mangium & 7.658 & $156.46 \pm 13.98^{\mathrm{b}}$ & $68.45 \pm 5.05^{\mathrm{c}}$ & $417.38 \pm 25.40^{\mathrm{e}}$ & $324.78 \pm 13.21^{\mathrm{a}, \mathrm{b}}$ \\
A. auriculiformis & 8.591 & $170.06 \pm 5.57^{\mathrm{b}}$ & $57.73 \pm 1.27^{\mathrm{b}}$ & $260.47 \pm 26.68^{\mathrm{c}}$ & $398.35 \pm 41.93^{\mathrm{b}}$ \\
A. leucophloea & 3.882 & $216.86 \pm 6.44^{\mathrm{c}}$ & $16.88 \pm 0.57^{\mathrm{a}}$ & $138.85 \pm 12.45^{\mathrm{b}}$ & $284.17^{\mathrm{b}} \pm 7.19^{\mathrm{a}}$ \\
A. crassicarpa & 3.010 & $259.09 \pm 29.16^{\mathrm{d}}$ & $65.24 \pm 4.44^{\mathrm{c}}$ & $370.99 \pm 11.25^{\mathrm{d}}$ & $1055.77^{\mathrm{a}} \pm 65.96^{\mathrm{c}}$ \\
A. decurrens & 3.596 & $101.16 \pm 21.08^{\mathrm{a}}$ & $18.48 \pm 1.04^{\mathrm{a}}$ & $87.02 \pm 10.24^{\mathrm{a}}$ & $366.20 \pm 55.00^{\mathrm{a}, \mathrm{b}}$ \\
\hline
\end{tabular}

Different letters indicate a significant difference $(p<0.05)$ according to Duncan's multiple-range test.

\subsection{Pharmacological Activity of Acacia Heartwood Methanolic Extracts}

The antioxidant activity of the five extracts varied according to the radical-scavenging (DPPH and ABTS) and reducing-power assays (FRAP). Antioxidant capacity using DPPH and ABTS ranged from 1.36 to 1.96 and 2.16 to $5.40 \mathrm{mmol} \mathrm{TE} / \mathrm{g}$ DE, respectively (Table 2). In comparison, the antioxidant capacity trend of these assays was relatively different. However, the A. crassicarpa extract exhibited the highest capacity, which was significantly different from other extracts $(p<0.05)$. A similar phenomenon was observed for the 
FRAP assay, with the antioxidant capacity of $A$. crassicarpa $(2.28 \mathrm{mmol} \mathrm{TE} / \mathrm{g} \mathrm{DE})$ extract being consistently highest $(p<0.05)$. In addition, $A$. auriculiformis extract exhibited the second highest capacity with regard to the DPPH and FRAP assays. On the other hand, the heartwood extract of $A$. leucophloea exhibited the second highest antioxidant capacity, which was not significantly different from A. auriculiformis in the ABTS assay $(p>0.05)$.

Table 2. Pharmacological activity of five Acacia heartwood methanolic extracts.

\begin{tabular}{|c|c|c|c|c|}
\hline \multirow{2}{*}{ Extracts } & \multirow{2}{*}{$\mathrm{LC}_{50}\left(\mu \mathrm{g} \cdot \mathrm{mL}^{-1}\right)$} & \multicolumn{3}{|c|}{ Antioxidant Capacity (mmol TE/g DE) } \\
\hline & & DPPH & ABTS & FRAP \\
\hline A. mangium & $2390.40 \underset{d}{ \pm} 326.71$ & $1.56 \pm 0.02^{\mathrm{c}}$ & $2.50 \pm 0.04^{\mathrm{c}, \mathrm{d}}$ & $0.70 \pm 0.08^{b, c}$ \\
\hline A. auriculiformis & $1411.54 \pm 97.67^{b}$ & $1.72 \pm 0.03^{b}$ & $2.89 \pm 0.17^{b, c}$ & $1.08 \pm 0.12^{b}$ \\
\hline A. leucophloea & $1418.21 \pm 62.65^{b}$ & $1.36 \pm 0.04^{\mathrm{d}}$ & $3.16 \pm 0.49^{b}$ & $0.92 \pm 0.09 \mathrm{~b}$ \\
\hline A. crassicarpa & $2054.09 \pm 92.74^{\mathrm{c}}$ & $1.96 \pm 0.07^{\mathrm{a}}$ & $5.40 \pm 0.10^{\mathrm{a}}$ & $2.28 \pm 0.32^{\mathrm{a}}$ \\
\hline A. decurrens & $566.10 \pm 5.83^{a}$ & $1.42 \pm 0.04^{\mathrm{d}}$ & $2.16 \pm 0.07^{\mathrm{d}}$ & $0.40 \pm 0.11^{\mathrm{c}}$ \\
\hline
\end{tabular}

The $\mathrm{LC}_{50}$ of the five extracts ranged from 566.10 to $2390.40 \mu \mathrm{g} / \mathrm{mL}$ (Table 2), reflecting the toxicity levels of the extracts. The A. decurrens and A. mangium extracts had the lowest and highest $\mathrm{LC}_{50}$ values, respectively. According to Meyer's toxicity index [33], only the A. decurrens extract was classified as toxic ( $\mathrm{LC}_{50}$ below $\left.1000 \mu \mathrm{g} / \mathrm{mL}\right)$. Clarkson's toxicity criteria [34] classified the $A$. decurrens extract into the low toxicity group $\left(\mathrm{LC}_{50}\right.$ between 500 and $1000 \mu \mathrm{g} / \mathrm{mL}$ ). As shown in Table 2, the trends for antioxidant capacity and toxicity varied significantly.

\subsection{Multivariate Analysis and Extract Selection}

The antioxidant activity, toxicity, and phytochemical profile were analyzed as a function of Pearson's correlation coefficient, yielding the correlation chart shown in Figure 1. The antioxidant capacity and toxicity toward $A$. salina were not significantly correlated in this study. The FRAP, DPPH, and ABTS assays were highly and significantly correlated $(r=0.79-0.96)$; however, all three methods displayed a low correlation with toxicity $(r=0.44-0.49)$, with low significance at the 99\% level.

The antioxidant activity according to all three assays exhibited a high and significant correlation with TPC and HT. In addition, TFC and CT had a significant correlation with antioxidant activity according to the DPPH assay, whereas there was a low correlation between TFC and FRAP $(p<0.05)$. TFC and CT exhibited a highly and significantly positive correlation with toxicity, as well as a significant correlation with each other.

Principal component analysis was performed along with cluster analysis to evaluate multiple variables in this study so as to distinguish between the five extracts. The first five principal components (PCs) yielded a cumulative $99.80 \%$ of the variance. PC1 and PC2 were chosen to explain the variance among individuals since they had an eigenvalue $>1$ according to Kaiser's rule, and their cumulative percentage variance was $90.13 \%$. The loading plot in Figure 2a shows the correlation of variables with PC1 and PC2 (Figure 2a). The antioxidant parameters TPC and HT were significantly correlated with PC1 but not with PC2. On the other hand, BSLT, TFC, and CT were more significantly correlated with PC2 but to a lesser extent.

The correlation of various variables with PC1 and PC2 made it possible to separate the five extracts using a score plot, through which clustering analysis revealed three distinct clusters with specific characteristics (Figure 2b). Cluster 1 (A. leucophloea and A. decurrens) was characterized by high toxicity, low antioxidant capacity according to the DPPH assay, and low flavonoid and condensed tannin contents. Cluster 2 (A. mangium and $A$. auriculiformis) was characterized by high flavonoid and condensed tannin contents. Cluster 3 (A. crassicarpa) was characterized by high antioxidant capacity according to all assays, as well as high TPC and HT contents. Accordingly, the A. crassicarpa extract was 
selected for its specific characteristics. Moreover, the A. auriculiformis extract (Cluster 2) was considered for further identification due to its potent antioxidant activity according to the FRAP and DPPH assays compared to the A. mangium extract.

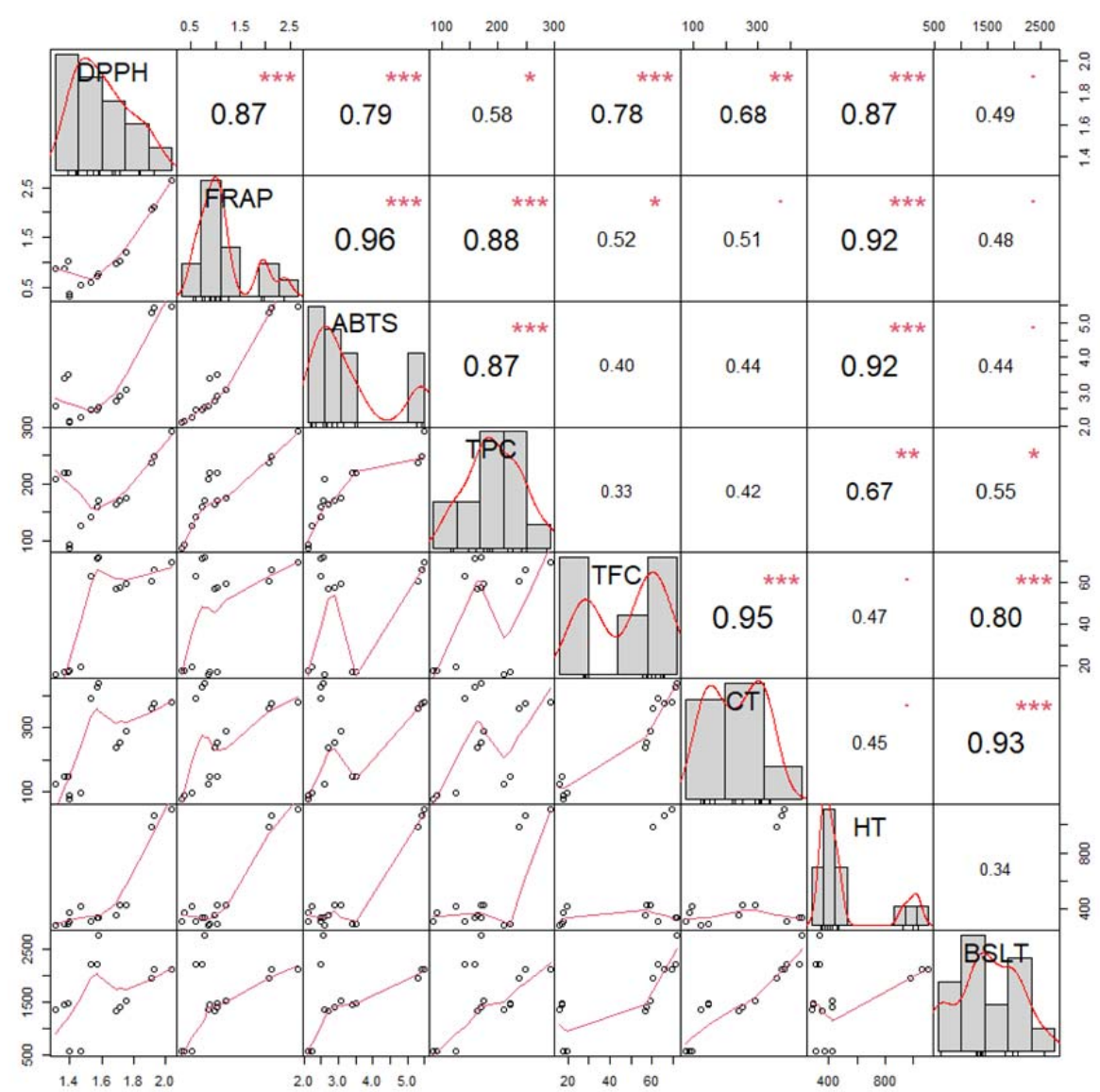

Figure 1. Pearson's correlation matrix of pharmacological and phytochemical variables describing Acacia heartwood extracts. The diagonal, top right, and bottom left boxes represent the data distribution of each variable, the correlation coefficient, and the bivariate scatter plot, respectively. *** $p<0.001,{ }^{* *} p<0.01,{ }^{*} p<0.05$.

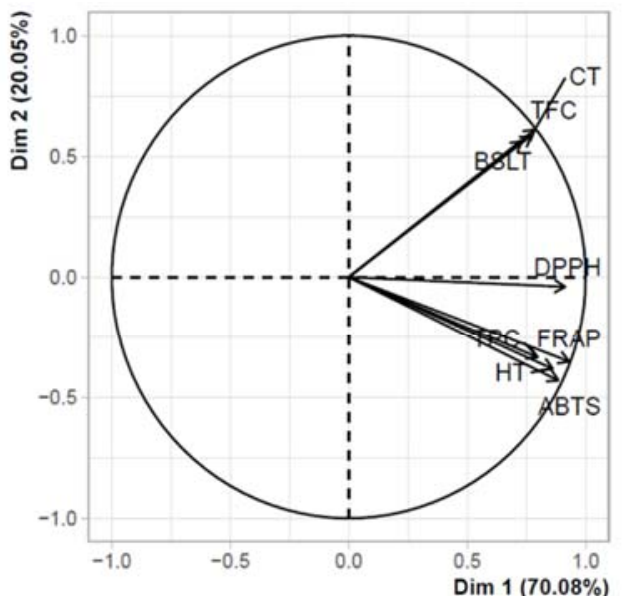

(a)

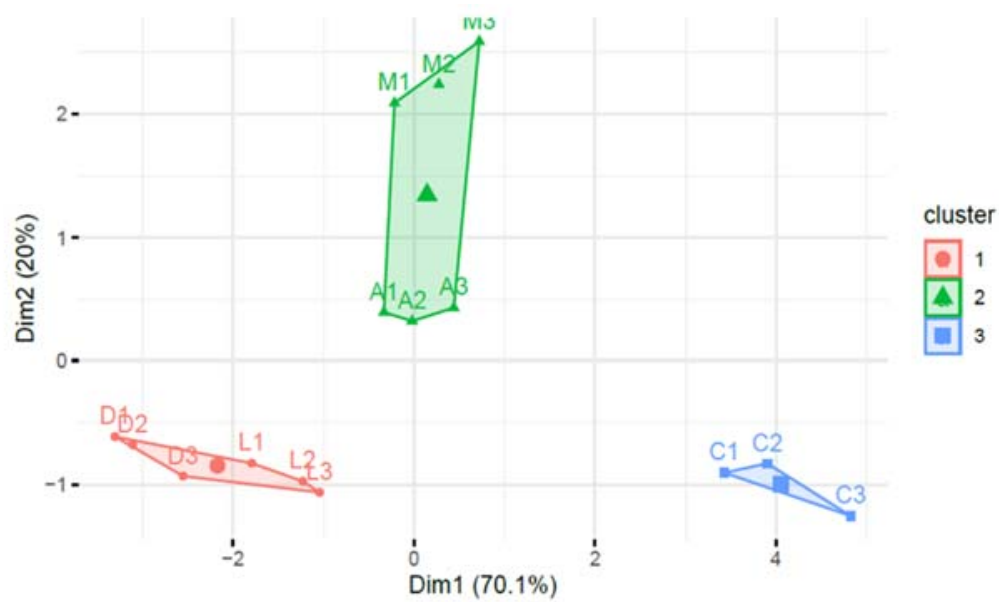

(b)

Figure 2. Results of principal component analysis followed by cluster analysis: (a) loading plot of pharmacological and phytochemical parameters; (b) score plot and clusters of the five Acacia heartwood extracts defined on the basis of pharmacological and phytochemical parameters. 


\subsection{Bioactive Compounds in Both Selected Extracts}

Extracts of A. auriculiformis and A. crassicarpa were dominated by flavonoid compounds (Table 3), which were more accumulated in the former $(57.46 \%)$ than the latter (29.85\%). Specifically, 5,7,3',5'-tetrahydroxyflavanone was identified in both extracts, with the highest percentage found in the A. auriculiformis extract (16.70\%). Additionally, other classes of compounds were detected in the A. auriculiformis and A. crassicarpa extracts, namely 3-( $3^{\prime}, 4^{\prime}$-dihydroxybenzyl)-7-hydroxychroman-4-one, digitopurpone, and onjixanthone II. To the best of our knowledge, this is the first time these compounds have been identified in Acacia heartwood extracts. Our results showed a different composition of flavonoids in the A. auriculiformis extract compared to previous reports [12,35].

Table 3. Compounds identified in A. crassicarpa and A. auriculiformis extracts by LC-MS/MS.

\begin{tabular}{ccccc}
\hline Compound Name & \multirow{2}{*}{ Class of Compound } & & $\mathbf{m} / \boldsymbol{z}$ & \multicolumn{2}{c}{ Abundance (\%) } \\
\cline { 4 - 5 } & & & $\mathbf{A}$ & $\mathbf{C}$ \\
\hline 3-(3,4-Dihydroxybenzyl)-7- & Flavonoid & 287.09 & 1.62 & - \\
hydroxychroman-4-one & Flavonoid & 287.05 & 24.95 & - \\
$5,7,2^{\prime}, 5^{\prime}$-Tetrahydroxyflavone & Flavonoid & 289.07 & 16.70 & 12.47 \\
$5,7,3^{\prime}, 5^{\prime}$-Tetrahydroxyflavanone & Flavonoid & 273.07 & 16.65 & - \\
Genistein & Flavonoid & 301.07 & - & 6.79 \\
3-Hydroxy-7-methoxy baicalein & Anthraquinone & 271.06 & - & 5.18 \\
Digitopurpone & Xanthonoid & 305.06 & - & 7.38 \\
Onjixanthone II & Flavonoid & 303.04 & - & 10.59 \\
Quercetin & & & &
\end{tabular}

\section{Discussion}

The percentage yield obtained from A. mangium heartwood was more significant than previous studies on samples from Queensland (Australia) and Papua New Guinea, with extract yields below 5\% [35]. The yield is affected by the growth environment. In Mihara et al. (2005) [12], the yields of A. auriculiformis extract produced from two trees originating from Papua New Guinea were $8 \%$ and $9.3 \%$, close to that produced in this study. Another study obtained an even higher yield of extract from the bark of $A$. decurrens [22]. The $A$. mangium extract had a higher yield compared to $A$. crassicarpa, in contrast with a previous study [36].

Previous studies have determined the content of phenolic compounds (including tannin and flavonoid) in Acacia plants. However, the content of these compounds in heartwood has not been compared across Acacia species to determine the best extract (i.e., one which shows good biological activity and a high phytochemical compound content). The phenolic contents in A. auriculiformis, A. mangium [12,35], and A. crassicarpa [36] have been shown to be relatively high, as also demonstrated in this study. Our study revealed significant phenolic content compared to previous studies using the bark of $A$. decurrens [37] and A. leucophloea [38]; this may have been due to the different growth location, as well as the part of the plant used. Phenolic compounds have also been identified from other parts in the same species, e.g., tannin from A. crassicarpa, and A. mangium bark extract $[39,40]$. The presence of phenolic compounds in the $A$. crassicarpa extract resulted in a high antioxidant capacity according to all assays used in this study, which indicated both radical-scavenging activity and reducing power. The DPPH and ABTS assays use single-electron transfer and hydrogen-electron transfer mechanisms, whereas the FRAP assay uses a single-electron transfer mechanism for measuring antioxidant activity [41]. Thus, the antioxidant activity of $A$. crassicarpa extract is likely mediated by both mechanisms.

As shown in previous research, the Acacia genus can be considered an alternative source of antioxidants. For example, the heartwood methanolic extract of $A$. catech $u$ exhibited the highest antioxidant activity of all parts according to four different assays [42]. Moreover, the antioxidant activity of $A$. crassicarpa knot wood has been identified using lipid 
peroxidation, revealing the lowest $\mathrm{IC}_{50}$ value among 20 other extracts from the same genus (A. mangium), as well as other genera [43]. Another study presented a higher antioxidant activity of $A$. auriculiformis heartwood extract compared to $A$. mangium according to a DPPH assay [12].

The BSLT provided a preliminary overview of the five extracts in terms of their toxicity. This method has been previously used to provide an overview of the toxicity of 120 plant extracts [44]. One study found a positive correlation between toxicity according to the BSLT and acute toxicity using rats [32]. Our results showed that the Acacia extracts were nontoxic with the exception of the $A$. decurrens extract. A similar result was also presented in [45], which found $A$. farnesiana leaf extract to be nontoxic. An association was determined between toxicity toward A. salina, toward rats/mice, and toward carcinoma cells. In a previous study by Calzada et al. (2020) [46], Annona macroprophyllata leaf extract exhibited the best anti-lymphoma activity, with a low $\mathrm{LC}_{50}$ value according to the BSLT but a high value for acute oral toxicity in female mice.

Pearson's correlation coefficient enabled the correlation of the samples on the basis of their biological activities and chemical profiles to determine the association between measured parameters. A high correlation for the three in vitro antioxidant activity methods used herein was found in a previous report $[29,47]$. On the other hand, no correlation with toxicity was found in another study [48]. The high correlation between phenolic content and antioxidant activity confirmed their contributions to the antioxidant properties of Acacia heartwood, as previously revealed in Acacia extract using different species [49]. Other studies have presented a low correlation between flavonoid content and toxicity toward cancer lines (Hela, SKOV3, and HT-29), but a high correlation with toxicity toward MCF-7 cells $[26,50,51]$. Our results with respect to toxicity remain unclear in terms of specificity toward cancer and healthy cells.

Principal component analysis and cluster analysis successfully reduced the dataset's complexity, enabling us to choose the best extract while considering all variables in this study. Accordingly, we demonstrated the effect of each parameter in differentiating extracts on the basis of their properties. Specific characteristics in each cluster facilitated the selection of two promising extracts. This technique has previously been used to analyze the connection between biological activity and phytochemical profile for selection of extracts/plants with the best biological activities [26,52,53].

The antioxidant activity and toxicity of the A. auriculiformis and A. crassicarpa extracts corresponded to their composition. Flavonoid compounds are known to have antioxidant activity [54]. We hypothesized that the antioxidant activity in our study was affected by the flavonoid compounds, which dominated in both the A. auriculiformis and A. crassicarpa extracts, as also demonstrated in the correlation matrix (Figure 1). As described above, the A. crassicarpa extract had the highest antioxidant activity, associated with the presence of 3-hydroxy-7-methoxy baicalein, digitopurpone, onjixanthone II, and quercetin, which were absent in A. auriculiformis. Onjixanthone II is used as a constituent in medicinal herbs to treat cognitive function [55]. Digitopurpone is an anthraquinone, which has previously been revealed to have strong antioxidant and anticancer activity [56,57].

\section{Conclusions}

Multivariate analysis encompassing antioxidant activity, toxicity, and phytochemical profile allowed the successful classification of Acacia heartwood extracts. A. auriculiformis and $A$. crassicarpa extracts were selected as the most promising, with strong antioxidant capacities and excellent phytochemical profiles, along with low toxicity. The identification of compounds in these extracts demonstrated the domination of flavonoid constituents, as well as anthraquinone and xanthone. These compounds were responsible for the antioxidant activity and toxicity of the extracts toward $A$. salina. These findings confirm the significant potential of Acacia wood extract for further development as an alternative source of antioxidants with low toxicity, as well as for sustainable production as a raw material. 
Author Contributions: Conceptualization, W.S., R.K.S. and I.B.; methodology, Y.H.P., W.S., R.K.S. and I.B.; validation, Y.H.P. and I.B.; formal analysis, Y.H.P.; investigation, Y.H.P.; writing-original draft preparation, Y.H.P.; writing-review and editing, Y.H.P., I.B., W.S. and R.K.S.; visualization, Y.H.P.; supervision, W.S., R.K.S. and I.B.; resources, W.S., R.K.S., I.B. and D. All authors have read and agreed to the published version of the manuscript.

Funding: This research was funded by the Deputy for Strengthening Research and Development, Ministry of Research and Technology, and the National Research and Innovation Agency Indonesia through the "Master-Doctoral Program for Outstanding Undergraduate Student", grant number 200/SP2H/PMDSU/DRPM/2020.

Institutional Review Board Statement: Not applicable.

Informed Consent Statement: Not applicable.

Data Availability Statement: All the data presented or analyzed during this study are included in the article.

Acknowledgments: We acknowledge Perum Perhutani (Indonesia) and the Forest Tree Seed Technology Research and Development Institute (Indonesia) for providing heartwood samples.

Conflicts of Interest: The authors declare no conflict of interest.

\section{References}

1. Brieger, K.; Schiavone, S.; Miller, F.J.; Krause, K.H. Reactive oxygen species: From health to disease. Swiss Med. Wkly. 2012, 142, w13659. [CrossRef]

2. Liu, Z.; Ren, Z.; Zhang, J.; Chuang, C.C.; Kandaswamy, E.; Zhou, T.; Zuo, L. Role of ROS and nutritional antioxidants in human diseases. Front. Physiol. 2018, 9, 477. [CrossRef]

3. World Health Organization. Global Cancer Observatory: Globocan 2018; International Agency for Research on Cancer (IARC): Lyon, France, 2018; Volume 256.

4. Singh, K.; Bhori, M.; Kasu, Y.A.; Bhat, G.; Marar, T. Antioxidants as precision weapons in war against cancer chemotherapy induced toxicity-Exploring the armoury of obscurity. Saudi Pharm. J. 2018, 26, 177-190. [CrossRef] [PubMed]

5. Deavall, D.G.; Martin, E.A.; Horner, J.M.; Roberts, R. Drug-induced oxidative stress and toxicity. J. Toxicol. 2012, 2012, 645460. [CrossRef]

6. Gorini, S.; De Angelis, A.; Berrino, L.; Malara, N.; Rosano, G.; Ferraro, E. Chemotherapeutic drugs and mitochondrial dysfunction: Focus on doxorubicin, trastuzumab, and sunitinib. Oxid. Med. Cell. Longev. 2018, 2018, 7582730. [CrossRef]

7. Nakagawa, T.; Ashour, A.; Amen, Y.; Ohnuki, K.; Fujimoto, N.; Shimizu, K. Antioxidant and anti-lipase compounds isolated from heartwood of Yakushima native cedar (Cryptomeria japonica). J. Wood Chem. Technol. 2019, 39, 305-312. [CrossRef]

8. Chang, S.T.; Wu, J.H.; Wang, S.Y.; Kang, P.L.; Yang, N.S.; Shyur, L.F. Antioxidant activity of extracts from acacia confusa Bark and Heartwood. J. Agric. Food Chem. 2001, 49, 3420-3424. [CrossRef] [PubMed]

9. Singhatong, S.; Leelarungrayub, D.; Chaiyasut, C. Antioxidant and toxicity activities of Artocarpus lakoocha Roxb. heartwood extract. J. Med. Plants Res. 2010, 4, 947-953. [CrossRef]

10. Wetwitayaklung, P.; Phaechamud, T.; Keokitichai, S. The antioxidant activity of caesalpinia sappan l. heartwood in various ages. Naresuan Univ. J. 2005, 13, 43-52.

11. Deepak, H.B.; Chandrasekaran, C.V.; Dethe, S.; Mundkinajeddu, D.; Pandre, M.K.; Balachandran, J.; Agarwal, A. Hepatoprotective and antioxidant activity of standardized herbal extracts. Pharmacogn. Mag. 2012, 8, 116-123. [CrossRef]

12. Mihara, R.; Barry, K.M.; Mohammed, C.L.; Mitsunaga, T. Comparison of antifungal and antioxidant activities of Acacia mangium and $A$. auriculiformis heartwood extracts. J. Chem. Ecol. 2005, 31, 789-804. [CrossRef]

13. Ghate, N.; Hazra, B.; Sarkar, R.; Mandal, N. Heartwood extract of Acacia catechu induces apoptosis in human breast carcinoma by altering bax/bcl-2 ratio. Pharmacogn. Mag. 2014, 10, 27-33. [CrossRef]

14. Afsar, T.; Khan, M.R.; Razak, S.; Ullah, S.; Mirza, B. Antipyretic, anti-inflammatory and analgesic activity of Acacia hydaspica R. Parker and its phytochemical analysis. BMC Complement. Altern. Med. 2015, 15, 136. [CrossRef]

15. Ghribia, L.; Ghouilaa, H.; Omrib, A.; Besbesb, M.; Hichem, H. Ben Antioxidant and anti-acetylcholinesterase activities of extracts and secondary metabolites from Acacia cyanophylla. Asian Pac. J. Trop. Biomed. 2014, 4, S417-S423. [CrossRef] [PubMed]

16. Sathya, A.; Siddhuraju, P. Protective effect of bark and empty pod extracts from Acacia auriculiformis against paracetamol intoxicated liver injury and alloxan induced type II diabetes. Food Chem. Toxicol. 2013, 56, 162-170. [CrossRef] [PubMed]

17. Krisnawati, H.; Kallio, M.; Kanninen, M. Acacia Mangium Willd.: Ecology, Silviculture and Productivity; Center for International Forestry Research (CIFOR): Bogor, Indonesia, 2011.

18. Hendrarti, R.L.; Nurrohmah, S.H.; Susilawati, S.; Budi, S. Budidaya Acacia Auriculiformis Untuk Kayu Energi, 1st ed.; Naiem, M., Mahfudz Prabawa, S.B., Eds.; IPB Press: Bogor, Indonesia, 2014. 
19. Nirsatmanto, A.; Sunarti, S. Sugarcane (Saccharum spp.): Breeding and genomics. In Advances in Plant Breeding Strategies: Industrial and Food Crops; Al-Khayri, J.M., Jain, S.M., Johnson, D.V., Eds.; Springer International Publishing: Cham, Switzerland, 2019; Volume 6, pp. 3-28. ISBN 9783030232658.

20. Lorenzo, P.; González, L.; Reigosa, M.J. The genus Acacia as invader: The characteristic case of Acacia dealbata Link in Europe. Ann. For. Sci. 2010, 67, 101. [CrossRef]

21. Sunardi, S.; Sulistijorini; Setyawati, T. Invasion of acacia decurrens willd. After eruption of Mount Merapi, Indonesia. Biotropia 2017, 24, 35-46. [CrossRef]

22. Okoli, B.; Jummai, A.; Molefe, N.; Ledwaba, I.; Modis, S. South African Invasive Tree: Studies of the Chemical and Biological Profiles of Acacia decurrens (Wild). Int. J. Chem. 2018, 10, 60. [CrossRef]

23. Hendrik, A.C.; Kusmana, C. Muhdin Stand and site characteristics of kabesak (Acacia leucophloea) in Timor Island, East Nusa Tenggara, Indonesia. J. Pendidik. Kehutan. Wallacea 2019, 8, 147-157. [CrossRef]

24. Badan Pusat Statistik. Statistik Produksi Kehutanan 2017; Badan Pusat Statistik (BPS): Jakarta, Indonesia, 2017 ; ISBN 2580-1740.

25. Badan Pusat Statistik. Statistik Produksi Kehutanan 2018; Badan Pusat Statistik (BPS): Jakarta, Indonesia, 2018 ; ISBN 2580-1740.

26. Batubara, I.; Komariah, K.; Sandrawati, A.; Nurcholis, W. Genotype selection for phytochemical content and pharmacological activities in ethanol extracts of fifteen types of Orthosiphon aristatus (Blume) Miq. leaves using chemometric analysis. Sci. Rep. 2020, 10, 20945. [CrossRef]

27. Herald, T.J.; Gadgil, P.; Perumal, R.; Bean, S.R.; Wilson, J.D. High-throughput micro-plate HCl-vanillin assay for screening tannin content in sorghum grain. J. Sci. Food Agric. 2014, 94, 2133-2136. [CrossRef] [PubMed]

28. Akter, S.; Netzel, M.E.; Tinggi, U.; Osborne, S.A.; Fletcher, M.T.; Sultanbawa, Y. Antioxidant rich extracts of terminalia ferdinandiana inhibit the growth of foodborne bacteria. Foods 2019, 8, 281. [CrossRef] [PubMed]

29. Dudonné, S.; Vitrac, X.; Coutière, P.; Woillez, M.; Mérillon, J.-M. Comparative Study of Antioxidant Properties and Total Phenolic Content of 30 Plant Extracts of Industrial Interest Using DPPH, ABTS, FRAP, SOD, and ORAC Assays. J. Agric. Food Chem. 2009, 57, 1768-1774. [CrossRef] [PubMed]

30. Lee, K.J.; Oh, Y.C.; Cho, W.K.; Ma, J.Y. Antioxidant and Anti-Inflammatory Activity Determination of One Hundred Kinds of Pure Chemical Compounds Using Offline and Online Screening HPLC Assay. Evidence-Based Complement. Altern. Med. 2015, 2015, 165457. [CrossRef] [PubMed]

31. Carballo, J.L.; Hernández-Inda, Z.L.; Pérez, P.; García-Grávalos, M.D. A comparison between two brine shrimp assays to detect in vitro cytotoxicity in marine natural products. BMC Biotechnol. 2002, 2, 17. [CrossRef]

32. Hamidi, M.R.; Jovanova, B.; Kadifkova Panovska, T. Toxicological evaluation of the plant products using Brine Shrimp (Artemia salina L.) model. Maced. Pharm. Bull. 2014, 60, 9-18. [CrossRef]

33. Meyer, B.N.; Ferrigni, N.R.; Putnam, J.E.; Jacobsen, L.B.; Nichols, D.E.; McLaughlin, J.L. Brine shrimp: A convenient general bioassay for active plant constituents. Planta Med. 1982, 45, 31-34. [CrossRef]

34. Clarkson, C.; Maharaj, V.J.; Crouch, N.R.; Grace, O.M.; Pillay, P.; Matsabisa, M.G.; Bhagwandin, N.; Smith, P.J.; Folb, P.I. In vitro antiplasmodial activity of medicinal plants native to or naturalised in South Africa. J. Ethnopharmacol. 2004, 92, 177-191. [CrossRef]

35. Barry, K.M.; Mihara, R.; Davies, N.W.; Mitsunaga, T.; Mohammed, C.L. Polyphenols in Acacia mangium and Acacia auriculiformis heartwood with reference to heart rot susceptibility. J. Wood Sci. 2005, 51, 615-621. [CrossRef]

36. Pietarinen, S.P.; Willför, S.M.; Sjöholm, R.E.; Holmbom, B.R. Bioactive phenolic substances in important tree species. Part 3: Knots and stemwood of Acacia crassicarpa and A. mangium. Holzforschung 2005, 59, 94-101. [CrossRef]

37. Okoli, B.J.; Modise, J.S. New Pharmacophore from the Stem Bark Fractions of Acacia decurrens (Willd), an Invasive South Africa Tree. J. Appl. Chem. 2017, 2017, 815278. [CrossRef]

38. Sulaiman, C.T.; Gopalakrishnan, V.K.; Balachandran, I. Phenolic Compounds and Antioxidant Properties of Selected Acacia species. J. Biol. Act. Prod. Nat. 2014, 4, 316-324. [CrossRef]

39. Zhang, L.; Chen, J.; Wang, Y.; Wu, D.; Xu, M. Phenolic extracts from Acacia mangium bark and their antioxidant activities. Molecules 2010, 15, 3567-3577. [CrossRef]

40. Ismayati, M.; Nakagawa-izumi, A.; Ohi, H. Structural elucidation of condensed tannin from the bark waste of Acacia crassicarpa plantation wood in Indonesia. J. Wood Sci. 2017, 63, 350-359. [CrossRef]

41. Gulcin, İ. Antioxidants and antioxidant methods: An updated overview. Arch. Toxicol. 2020, 94, 651-715. [CrossRef] [PubMed]

42. Guleria, S.; Tiku, A.K.; Singh, G.; Vyas, D.; Bhardwaj, A. Antioxidant activity and protective effect against plasmid DNA strand scission of leaf, bark, and heartwood extracts from Acacia catechu. J. Food Sci. 2011, 76, C959-C964. [CrossRef]

43. Pietarinen, S.P.; Willför, S.M.; Ahotupa, M.O.; Hemming, J.E.; Holmbom, B.R. Knotwood and bark extracts: Strong antioxidants from waste materials. J. Wood Sci. 2006, 52, 436-444. [CrossRef]

44. Krishnaraju, A.V.; Rao, T.V.N.; Sundararaju, S.; Vanisree, M.; Tsay, H.-S.; Subbaraju, G. V Assessment of bioactivity of some Sudanese medicinal plants using brine shrimp (Artemia salina) lethality assay. J. Chem. Pharm. Res. 2012, 4, 5145-5148.

45. Ramli, S.; Harada, K.I.; Ruangrungsi, N. Antioxidant, antimicrobial and cytotoxicity activities of Acacia farnesiana (L.) Willd. Leaves ethanolic extract. Pharmacogn. J. 2011, 3, 50-58. [CrossRef]

46. Calzada, F.; Ramirez-Santos, J.; Valdes, M.; Garcia-Hernandez, N.; Pina-Jiménez, E.; Ordoñez-Razo, R.M. Evaluation of Acute Oral Toxicity, Brine Shrimp Lethality, and Antilymphoma Activity of Geranylgeraniol and Annona macroprophyllata Leaf Extracts. Rev. Bras. Farmacogn. 2020, 30, 301-304. [CrossRef] 
47. Senhaji, S.; Lamchouri, F.; Toufik, H. Phytochemical Content, Antibacterial and Antioxidant Potential of Endemic Plant Anabasis aretioïdes Coss. \& Moq. (Chenopodiaceae). Biomed. Res. Int. 2020, 2020, 6152932. [CrossRef] [PubMed]

48. Sammar, M.; Abu-Farich, B.; Rayan, I.; Falah, M.; Rayan, A. Correlation between cytotoxicity in cancer cells and free radicalscavenging activity: In vitro evaluation of 57 medicinal and edible plant extracts. Oncol. Lett. 2019, 18, 6563-6571. [CrossRef]

49. Sowndhararajan, K.; Joseph, J.M.; Manian, S. Antioxidant and free radical scavenging activities of Indian acacias: Acacia leucophloea (Roxb.) willd., Acacia ferruginea dc., Acacia dealbata link. and Acacia pennata (L.) willd. Int. J. Food Prop. 2013, 16, 1717-1729. [CrossRef]

50. Eddebbagh, M.; Messaoudi, M.; Abourriche, A.; Berrada, M.; Attaleb, M.; Benbacer, L.; Bennamara, A. Correlation of the Cytotoxic and Antioxidant Activities of Moroccan Pomegranate (Punica Granatum) with Phenolic and Flavonoid Contents. J. Pharm. Pharmacol. 2016, 4, 511-519. [CrossRef]

51. Tuy-On, T.; Itharat, A.; Maki, P.; Thongdeeying, P.; Pipatrattanaseree, W.; Ooraikul, B. In Vitro Cytotoxic Activity against Breast, Cervical, and Ovarian Cancer Cells and Flavonoid Content of Plant Ingredients Used in a Selected Thai Traditional Cancer Remedy: Correlation and Hierarchical Cluster Analysis. Evidence-based Complement. Altern. Med. 2020, 2020, 8884529. [CrossRef] [PubMed]

52. Fernandes, R.P.P.; Trindade, M.A.; Tonin, F.G.; Lima, C.G.; Pugine, S.M.P.; Munekata, P.E.S.; Lorenzo, J.M.; de Melo, M.P. Evaluation of antioxidant capacity of 13 plant extracts by three different methods: Cluster analyses applied for selection of the natural extracts with higher antioxidant capacity to replace synthetic antioxidant in lamb burgers. J. Food Sci. Technol. 2016, 53, 451-460. [CrossRef] [PubMed]

53. Fujimura, Y.; Kawano, C.; Maeda-Murayama, A.; Nakamura, A.; Koike-Miki, A.; Yukihira, D.; Hayakawa, E.; Ishii, T.; Tachibana, H.; Wariishi, H.; et al. A Chemometrics-driven Strategy for the Bioactivity Evaluation of Complex Multicomponent Systems and the Effective Selection of Bioactivity-predictive Chemical Combinations. Sci. Rep. 2017, 7, 6-10. [CrossRef]

54. Panche, A.N.; Diwan, A.D.; Chandra, S.R. Flavonoids: An overview. J. Nutr. Sci. 2016, 5, e47. [CrossRef] [PubMed]

55. Wagner, H.; Püls, S.; Barghouti, T.; Staudinger, A.; Melchart, D. Radix Polygalae-Yuanzhi. In Chromatographic Fingerprint Analysis of Herbal Medicines; Wagner, H., Püls, S., Barghouti, T., Staudinger, A., Melchart, D., Eds.; Springer International Publishing: Cham, Switzerland, 2017; Volume V, pp. 103-115. ISBN 978-3-319-67061-4.

56. Cano, P.; Echavarren, A.; Prados, P.; Fariña, F. Polycyclic Hydroxyquinones. 13.1 A Novel Synthesis of Islandicin and Digitopurpone. J. Org. Chem. 1983, 48, 5373-5376. [CrossRef]

57. Eom, T.; Kim, E.; Kim, J.S. In vitro antioxidant, antiinflammation, and anticancer activities and anthraquinone content from rumex crispus root extract and fractions. Antioxidants 2020, 9, 726. [CrossRef] 